\title{
REVIEWS
} for Study Purposes in Minimally Invasive Dentistry

${ }^{1}$ Department of Conservative Dentistry with Endodontics, Medical University of Silesia, Poland

${ }^{2}$ Department of Organic, Bio-Organic Chemistry and Biotechnology, Technical University of Silesia in Gliwice, Poland

${ }^{3}$ Department of Preventive Dentistry and Endodontics, Medical University of Silesia in Katowice, Poland

A - research concept and design; B - collection and/or assembly of data; $\mathbf{C}$ - data analysis and interpretation;

$\mathbf{D}$ - writing the article; $\mathbf{E}$ - critical revision of the article; $\mathbf{F}$ - final approval of article

\begin{abstract}
Artificially induced demineralization of enamel is frequently used during laboratory tests, particularly in minimally invasive dentistry. The aim of this study was to analyze demineralization techniques of hard tooth tissue applicable in the research of materials in minimally invasive dentistry. The most important factor taken into consideration when designing a method is to make a model as closely similar to the natural environment of the human oral cavity as it is possible. In vitro models allow us to maintain stability and control over the environment and guarantee repeatability of the results. There are main models to produce dental caries outside of the body. The first model is chemical and it uses acids. It is simplified and reflects the actual environment of the oral cavity to a lesser degree. The second model is biological and it is more accurate as it uses microorganisms which build the dental plaque. Among in vitro protocols are also used $\mathrm{pH}$-cycling models. Based on the available literature, it was found that bovine teeth and human teeth with demineralization diagnosed while still inside the oral cavity are the most frequently used kind of specimens in research conducted with use of the chemical model. Not a single case of use of the biological and $\mathrm{pH}$-cycling models were found in the available literature related to the research of infiltrants in minimally invasive dentistry (Adv Clin Exp Med 2015, 24, 5, 891-898).
\end{abstract}

Key words: enamel, demineralization, dentistry.

Dental caries is a widely known disease which affects people of all ages, both genders and is common in the whole world. It is a limited pathological process caused by factors from outside of the body. It begins at the tooth surface in a form of a small lesion which progresses and causes a macroscopic loss, which can be then detected during an intraoral examination of the patient. Initially, damages caused by demineralization at the ultrastructural level can be seen only with the use of an electron microscope. Such damage cannot be detected by a dentist during a check-up. Ongoing loss of mineral material becomes visible for the dentist as decreased translucency of enamel. After that, the therapeutic process focuses on minimally invasive procedures, e.g. using remineralization or infiltration techniques. Presence of active dental plaque is an additional diagnostic factor, also significantly contributing to occurrence of caries [1]. Despite many years of research, the mechanisms which control etiopathogenesis of dental caries have not been fully explained yet. Bacterial microflora inside the oral cavity is considered to cause dental caries [2]. Despite the assumption that dental caries is caused by a sum of several factors, it is thought that presence of bacterial plaque is the necessary factor for its occurrence. The presence of plaque alone is necessary, however not enough to cause carious lesion $[3,4]$. Other factors which are responsible for the occurrence of dental caries are: the presence of carious carbohydrates in food, susceptibility of tooth tissue to decalcification (genetic predisposition), the time during which harmful factors affect the tooth tissue [2]. 
Bacteria of the oral cavity are called "opportunistic amphibionts", i.e. having a dual attitude towards their host. In some conditions they can be harmless symbionts, in others they are pathogenic. Long-term research revealed that various stages of cariogenesis are accompanied by various microorganisms present in the dental plaque. Cariogenic bacteria are only those that initiate the process of cariogenesis (S. mutans, S. sanguis, S. salivarius, S. faecalis). S. mutans is considered to be the most cariogenic strain as it is very tolerable to acid environment, synthesizes glucan, can produce and store metabolic reserve in a form of glycogen. Lactobacillus acidophilus, which significantly participates in cariogenesis, is an acid-producing bacteria, however it is unable to initiate the cariogenic process [5].

Streptococci and filamenous bacteria produce extracellular saccharides (glucans and fructans). Glucans have a high molecular mass, high viscosity and, therefore, easy absorption to the enamel and bacteria, which facilitates their accumulation within the dental plaque. They influence the density of plaque and its adherence to tooth tissue, therefore also its durability.

Dental plaque appears on the surface of a tooth covered with acquired pellicle and is a highly-specialized form of life with the environment favorable for various microorganisms. It contains live and dead bacteria cells, glicoproteins from saliva and extracellular products of bacterial exchange, as well as desquamated epithelial cells, leukocytes, calcium and phosphor.

Cariogenic microorganisms feed on carbohydrates delivered with the food, which is also a substrate for appearance of acids and decreases the $\mathrm{pH}$ factor of plaque. Sucrose is most frequently used by the plaque bacteria as it is the only substrate to produce insoluble part of the intracellular matrix, i.e. mutant. Even a small delivery of the substrate is immediately metabolized by them. During the process of glycolysis, a bacterial cell produces energy necessary for living and multiplication. The end products of that process are organic acids: lactic or acetic. Which acid is produced depends on the strain of the bacteria and concentration of oxygen in the environment. Starch is the least important of carbohydrates which can participate in the cariogenic process. Its large molecular mass does not allow it to diffuse inside the dental plaque. However, long presence of starch on the surface of teeth and the influence of amylase can cause its hydrolysis to monosaccharaides $[1,6]$.

Saliva plays a significant role in the cariogenic process. It mechanically cleanses the surface of teeth from bacteria and food remains. It also includes carbon-hydroxycarbonate and phosphate buffers which participate in the maintenance of acid-base homeostasis. The speed of secretion and composition of saliva is an important factor of protection. Increased secretion occurs during chewing and as a reaction to sour taste. Chewing-stimulated saliva contains increased concentration of calcium and phosphate ions. An increased susceptibility to caries was found in the case of patients with saliva secretion disorders $[4,6]$. Inorganic components of saliva, such as calcium and phosphor participate in the maintenance of mineral balance between hydroksyapatite of enamel and saliva. At the neutral level of $\mathrm{pH}$ (5.5), saliva is a supersaturated solution of those minerals in comparison to hydroksyapatites of enamel. Remineralization occurs in such an environment. If acid metabolites of glycolysis are not neutralized, mainly by the buffer properties of saliva, $\mathrm{pH}$ of the dental plaque decreases which, in turn, creates favorable conditions for demineralization of enamel. Critical $\mathrm{pH}$ level for plaque below which decalcification occurs is between 5.5 and 5.0. A decrease in the $\mathrm{pH}$ value leads to dissolution of enamel and transportation of phosphate and calcium ions to the environment. Therefore, maintenance of a balance between demineralization and remineralization of enamel is a basic requirement for the preservation of continuity of the hard tooth tissue. Lack of any attempts to improve the situation at this stage causes further progression of lesions in the dentine and, furthermore, the pulp [2].

\section{Structure of Enamel}

Enamel is the outside layer of every tooth. It is the most mineralized and therefore the hardest structure in the human body. Those features are necessary for the function it fulfills. Every-day enamel is subject to a wide range of stress, strain and shear resulting from contact with adjacent teeth and food. In contrast to other calcified elements of the human skeleton system, enamel cannot be easily restored. Therefore, it has to be hard and durable [7].

Enamel does not have a cellular membrane. Its structure is shaped for many years through the process of odontogenesis. Enamel comes from ameloblasts originating from ectoderm [8]. The correct course of odontogenesis, the calcium-phosphate transformation and the right amount of A, $\mathrm{C}$ and $\mathrm{D}$ vitamins in the diet influence the overall quality of hard tooth tissues. Enamel contains mostly mineral substances (95\%), as well 
as organic substances and water (5\%). The basic structural unit of enamel is a prism built from millions of hydroxylapatite crystals $\mathrm{Ca}_{10}\left(\mathrm{PO}_{4}\right)_{6}(\mathrm{OH})_{2}$ and the non-apatite phase, which includes calcium carbonate and amorphous phosphates. The surface of the crystal adsorbs molecules and ions. Fluoride ions are the most important. The detailed composition of enamel can be found in Table 1 [5].

The surface layer of enamel is built from dense, adjacent hydroxylapatite crystals (HA) which create the enamel prism. This layer has the highest concentration of phosphate ions, fluorine, calcium and chlorine, which results in its hardness. The spaces between prisms are filled with interprism substance rich in organic content and water. The process of calcification, or hardening, decreases its amount. Layers of enamel adjacent to dentine are less hard, which is related to a higher content of magnesium, sodium and potassium ions, as well as a higher concentration of interprism substance. As the number of hydroxylapatite crystals decreases, they are less packed and prisms are thinner in the deeper layers [1].

The outside layer of enamel is more resistant to dissolution, mainly due to an increased content of fluorine and less carbonates than in the outer layers. The presence of carbonates and citrates intensifies solubility of crystals, which in turn causes dental caries. The degree of solubility is also influenced by the content of the interprism substance. Another factor which influences solubility of enamel is $\mathrm{pH}$ level of the environment in which it exists. Hydroxylapatite reaches its most stable form in the environment with $\mathrm{pH}$ level equal 7.4 [1].

If fluorine is present in the environment, replacement of hydroxylapatite ions $\left(\mathrm{OH}^{-}\right)$with fluoride ions may take place. The result is fluorapatite:

It is significantly more resistant to dissolution than hydroxylapatite, which increases resistance

Table 1. Enamel composition $[3,5]$

\begin{tabular}{|l|l|}
\hline & Dry mass \% \\
\hline Calcium & $34-39$ \\
\hline Phosphor & $16-18$ \\
\hline Carbonate & $2.0-3.6$ \\
\hline Sodium & $0.3-0.9$ \\
\hline Magnesium & $0.3-0.6$ \\
\hline Chloride & $0.2-0.3$ \\
\hline Mineral components & 95 \\
\hline Organic components + water & 5 \\
\hline
\end{tabular}

of enamel to dental caries. However, total replacement of ions never takes place, therefore pure fluorapatite never occurs [9].

Thickness of enamel ranges from $2.4 \mathrm{~mm}$ in premolars and molars to $2.6 \mathrm{~mm}$ on the chewing surface. The enamel layer is the thinnest near the tooth neck and amounts only to $0.1 \mathrm{~mm}$ [1]. Hydroxylapatite and enamel are both colorless. The color of teeth is given by slightly yellow dentin. Demineralization, which means the removal of mineral content from the surface of crystals, occurs as a result of organic acids produced by the dental plaque bacteria. That, in turn, increases the spaces between crystals and makes enamel more porous. When water in pores is replaced with air, enamel changes its color to chalk white [3]. This stage of carious lesion is visible during a dental check-up and is called the initial caries (white spot).

\section{Types of Carious Lesions}

There are numerous clinical divisions of caries depending on the assessment criteria (e.g. type - primary and secondary, shape, position, depth, location) [5]. According to the World Health Organization, carious lesions can be divided into 4 categories according to the degree of decay: caries incipiens, caries superficialis, caries media and caries profunda [5].

Clinical picture of caries incipiens is the so-called "white spot", which is an opaque, white area which can be easily differentiated from healthy enamel. If the white spot is visible only after drying up the surface, it means the lesion is not very advanced. Sometimes the spot turns brown due to adsorption of pigments into enamel pores. Progression of such lesion may be stopped by regular removal of dental plaque and treatment of the area with minimally invasive procedures, such as remineralization or infiltration. This kind of dental caries does not damage the surface of enamel - no lesion occurs [5].

In case of the other types of caries, according to WHO, minimally invasive dentistry is not applicable anymore. In those cases the only procedures that can de facto lead to success are surgical procedures to remove the carious layer and damaged tissue with use of rotary tools or methods alternative to mechanical, such as e.g. chemical treatment (Carisolv), air abrasion and supersonic treatment [10]. Those include: caries superficialis, caries media and caries profunda. 


\section{Effect of Demineralization}

Demineralization of enamel, i.e. dissolution of hydroxylapatite, is a chemical process which can be shown with a series of equations $[3,11]$ :

$$
\begin{gathered}
\mathrm{Ca}_{10}\left(\mathrm{PO}_{4}\right)_{6}(\mathrm{OH})_{2}+8 \mathrm{H}^{+} \rightarrow 10 \mathrm{Ca}^{2+}+ \\
+6 \mathrm{HPO}_{4}^{2-}+2 \mathrm{H}_{2} \mathrm{O} \\
\mathrm{Ca}_{10}\left(\mathrm{PO}_{4}\right)_{6}(\mathrm{OH})_{2}+14 \mathrm{H}^{+} \rightarrow 10 \mathrm{Ca}^{2+}+ \\
+6 \mathrm{HPO}_{4}^{-}+2 \mathrm{H}_{2} \mathrm{O}
\end{gathered}
$$

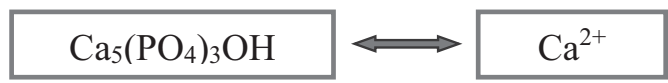

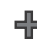

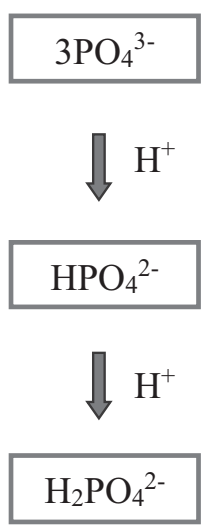

surface of crystals [6]. The result of this reaction is $\mathrm{OH}^{-}$and $\mathrm{PO}_{4}{ }^{3-}$ ions which then transform into water and $\mathrm{HPO}_{4}{ }^{2-}$ ions (Fig. 2). That removes $\mathrm{OH}^{-}$and $\mathrm{PO}_{4}{ }^{3-}$ ions from the solution which becomes unsaturated.

Hydroxylapatite dissolves when the solution lacks one of the aforementioned ions. When calcium, phosphate $\left(\mathrm{PO}_{4}{ }^{3-}\right)$ and $\mathrm{OH}^{-}$ions are accumulated, dissolution slows down to the moment when the solution reaches saturation, then the pro-

Fig. 1. Diagram of hydroxyapatite demineralization process [3]

Loss of minerals in enamel is caused by acids which come from inside and outside the body. Lactic and acetic acids are the main contributors to that process. They penetrate the space between prisms of enamel as neutral ions. Then they dissociate which lowers $\mathrm{pH}$ of the liquid situated in those spaces. This, in turn, produces $\mathrm{H}^{+}$ions that dissolve hydroxylapatite on the

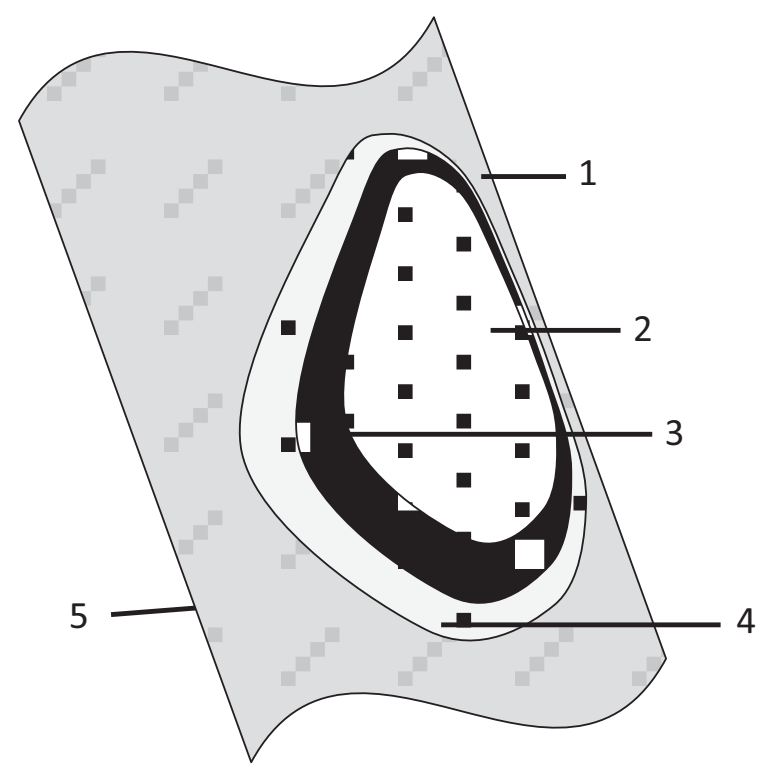

Fig. 2. White carious spot (1 - surface layer, 2 - central layer, 3 - dark layer, 4 - translucent layer, 5 - enamel-dentin border) cess stops completely. Solubility of hydroxylapatite is strictly related to $\mathrm{pH}$ level of water in which it is dissolved. Hydroxylapatite with $\mathrm{pH}$ of 7.4 is the most stable form of calcium phosphate, while the critical value amounts to 5.5 [3]. The critical pH value for fluorapatite is 4.5 [9].

\section{Initial Caries and White Carious Spot}

Carious changes are described separately for the enamel layer and for dentin. The reason for this is different origin of both tissues as well as different reactions to damaging stimuli. Enamel does not have a cell structure, so it cannot produce any defense response, while dentin contains odontoblast processes (pulp cells), nerve fibers and tissue fluid. It is in some way integrated with pulp, creating a pulp-dentine complex. Early carious lesions can be found in enamel [5].

In initial caries the surface of enamel remains smooth. Actual demineralization affects the subsurface layer. A lesion on the surface of smooth teeth is visible under a microscope as a cone with the wider end downwards. This is due to demineralization advancing along prisms of enamel and laterally. Examination of vertical sections of enamel, including clinical studies, shows 4 layers: surface, central, dark and translucent [12]. 
The surface layer is $20-50 \mu \mathrm{m}$ deep and resembles healthy enamel. It covers the carious lesions and features high mineralization. The volume of pores amounts to $1 \%$, just like the loss of mineral substances $[5,12]$. Two theories are related to the creation of the surface layer. The first theory talks about the presence of inhibitors which prevent its dissolution, while the second theory suggests a relation between the dissolution processes and continuous reconstruction of enamel. The thickness of this layer changes only during its creation. When it is fully formed, it does not change anymore [11].

Another layer, central, is the most affected by lesions. Loss of mineral substance varies here from $5 \%$ in the peripheral part to $25 \%$ in the central part. The dark layer has a loss of mineral substances of $2 \%$ to $5 \%$ while the pores amount for $2 \%$ to $4 \%$. Quite high porosity gives it the dark tint. The last, translucent layer, does not appear during each carious lesion. The increase in porosity amounts to approximately $1 \%$. This layer is adjacent to healthy enamel and its occurrence is the first symptom of a pathological process taking place [12].

Hydroxylapatite in the subsurface layer dissolves mainly at the boundary of demineralized and healthy enamel. Relocation of this boundary is considered to signal development of caries. It is identified with the surface where dissolution of hydroxylapatite by acids occurs with the highest yield [11].

A white spot caused by demineralization of enamel is the earliest visible symptom of a carious lesion. Despite the loss of mineral substances, the surface of enamel remains virtually unchanged. The degree of translucency of enamel depends on the volume of space between crystals: the biggest the space, the more mat and whiter the spot. During the initial phase, the surface of a tooth has to be dried up in order to see a carious lesion. During further progression it is no longer necessary. Translucency of enamel depends on the presence of water around prisms. As a result of demineralization, water is replaced by air. The effect of light scattering in a non-homogeneous medium is a function of the delta of refraction of the two binding elements. The refraction rate for enamel is 1.65 while for water and air it is 1.33 and 1.00 , respectively. Higher difference in the enamel-air setup results in a higher dispersion rate [13]. If the white spot appears only after the surface of a tooth was dried up with air, the lesion is small when analyzed with a microscope. However, if it becomes visible even without drying, it means the lesion is more advanced $[5,13,14]$.

Sometimes it also happens that the spot becomes brown. That is caused by infiltration of pores with pigments. Initial carious lesions, both white and brown spots, can stay on teeth for a long time without further development. Such lesion is called static or stopped caries $[5,14]$.

The structure of layers in initial caries conditions the development of microinvasive dentistry. Its purpose is to prevent necessity of using rotary tools that mechanically disrupt continuity of hard tooth tissues. The trends of that development focus on: 1) "reinforcement" of the surface layer which features high mineralization anyway; 2) separation of a demineralized surface of a tooth from the environment of the oral cavity and dental plaque; 3 ) infiltration of the central layer after getting through the barrier which is the highly mineralized surface layer, however without disrupting its continuity [14, 15].

\section{Controlled Demineralization - How to Achieve Initial Caries in In Vitro Conditions}

There are two main models to produce dental caries outside of the body. The first model is biological and it is more accurate as it uses microorganisms which build the dental plaque. The second model is chemical and it uses acids. It is simplified and reflects the actual environment of the oral cavity to a lesser degree. Among in vitro protocols are also used $\mathrm{pH}$-cycling models.

\section{Biological Model}

Selection of an appropriate bacteria strain which will be responsible for initiation and development of dental caries is the most important element of the biological model. S. mutans streptococci are the most commonly used strain, while Lactobacillus coccobacilli are responsible for further progression of caries but cannot initiate the process by itself. A smooth surface of clean enamel makes adhesion of bacteria cells difficult. Saliva is another very important element of the model. As it is widely known, it covers all surfaces in the oral cavity and participates in the processes of both demineralization and remineralization. It is also an important factor which decides about adhesion of bacteria to enamel. Saliva glycoproteins create a film layer on a clean tooth to which bacteria of dental plaque adheres. Saliva used in in vitro tests should be human as it contains various compounds, e.g. proteins. The living environment for the bacteria is provided by a base with carbohydrates necessary for their growth. S. mutans 
bacteria develop best in presence of sacharose. Its fermentation produces substances which facilitate adhesion and caries-inducing acids, mainly lactic acid. Another way is to use ready growth media with sacharose which are commercially available. The temperature of the process should be $37^{\circ} \mathrm{C}$ in aerobic or anaerobic environment and the whole process should last from several to several dozen days [1].

\section{Chemical Model}

The chemical model assumes the creation of conditions in which dental caries occur through use of acids, acid buffers or silica gels [1]. The available literature on the research and infiltration techniques of carious lesions suggests that the researchers use a method from 1985 created and described by a team of Buskes et al. [16]. According to that method, teeth are soaked for 4 weeks in an acid buffer with the main ingredient being acetic acid $(50 \mathrm{mM})$ with addition of MHDP $(6 \mathrm{M})$, Ca$\mathrm{Cl}_{2} 2 \mathrm{H}_{2} \mathrm{O}(3 \mathrm{mM})$ and $\mathrm{KH}_{2} \mathrm{PO}_{4}(3 \mathrm{mM})$. Buffer's $\mathrm{pH}$ should equal 5 and the temperature of the process should be $37^{\circ} \mathrm{C}$ [16].

Methanehydroxydiphosphate (MHDP) is a chemical compound from the bisphosphonate group. Bisphosphonates (Fig. 3) are analogs of pyrophosphate in which the oxygen atom between the two phosphorous atoms is replaced with a carbon atom, creating a P-C-P bond. As a result, those compounds show high affinity to hydroxylapatite crystals and they are also resistant to enzymes [17]. $\mathrm{R}_{1}$ side chain decides about affinity to the bone material. When a hydroxyl group $\left(\mathrm{OH}^{-}\right)$is present, affinity increases. $\mathrm{R}_{1}$ side chain is responsible for strength of the compound. Bisphosphonates are used as drugs in treatment of osteoporosis and they have antiresorptive properties [18].

An early carious lesion affects the subsurface layer. The surface layer of enamel remains unchanged. Formation of the surface layer may be caused by protective substances which inhibit dissolution of enamel. Those include proteins present in saliva, polyphosphates and bisphosphonates like MHDP which have a high ability to react with

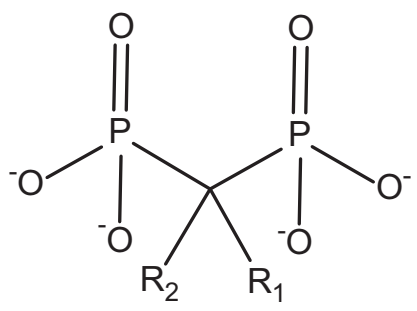

Fig. 3. General chemical formula of bisphosphonates [18] hydroxylapatite. Therefore, the surface layer includes partially demineralized enamel with calcium and phosphate ions washed out from deeper regions [19]. MHDP acts as a demineralization inhibitor on the surface layer but also causes expansion of the spaces between crystals due to a partial dissolution of the boundaries of some hydroxylapatite crystals in the subsurface layer [20].

\section{pH-Cycling Model}

Ten Cate and Duijsters produced the genesis of modern $\mathrm{pH}$-cycling models (in 1982). Every day, in our mouth, a dental substrates as enamel, dentin and cement are exposed to two processes demineralization and reminerazation. It is related to the influence of fluoridated dentifrices on hard dental tissues [21]. Generally, in vitro $\mathrm{pH}$-cycling models can be classified into models: - progression - remineralizing - reversal - remineralizing.

These models are depending on the flow of minerals to or from the dental substrates. Usually, the models employ an initially sound substrate and the response changeable will analyze the potential of the dentifrice to decrease the loss of minerals from the substrate to the demineralizing solution or the increase of minerals from the remineralizing solution.

Substrates with artifical caries lesion can also be employed to measure the further demineralization (or remineralization) in demineralizing (or remineralizing) models [21].

Artificial caries lesions of the substrates are in beginning produced by immersing them in buffered lactate or acetate gels or solutions, undersaturated in respect to apatite, with a $\mathrm{pH}$ 4.4-5.0, for a time between $16 \mathrm{~h}-28$ days. This different protocol leads to various types of lesions. It is required to obtain subsurface demineralization of enamel in the field of minimally invasive dentistry. The surface layer should be less demineralized than subsurface one. The presence of calcium, fluoride and phosphate in solution is very important for the preservation of the surface layer. In addition to this, $\mathrm{pH}$ and the time after an initial demineralization, as the saturation might be reached with time, depends on the volume and viscosity of the demineralization solution relative to the area of enamel exposed to it. There are many factors interacting with each another in a $\mathrm{pH}$-cycling model: the presence of calcium and phosphate and fluoride in the solution, $\mathrm{pH}$ and the time after an initial demineralization, as the saturation might be reached with time, depending on the volume and viscosity of the demineralization solution relative to the area of enamel exposed to it. 
As reported in the literature, $\mathrm{pH}$-cycling models involve exposure of dental substrates to combinations of demineralization and remineralization [21]. These combination experiments are designed to simulate the dynamics of mineral loss and profit involved in caries formation.

Research studies frequently use demineralization of enamel which is artificially induced, especially as far as minimally invasive dentistry is concerned. Those studies use both human and bovine teeth (including ovine and equine specimens). It is difficult to obtain human teeth to diagnose initial caries, although such studies also exist [22, 23]. Meyer-Lueckel and Paris studied penetration properties of an experimentary infiltrant reaching inside enamel using extracted human molars and premolars with initial caries diagnosed as a white spot prior to their removal $[22,23]$. However, it is much easier to cause it to occur artificially in a chosen part of the enamel after a tooth is removed from the oral cavity. Many researchers used bovine teeth instead of human ones [24-26]. Meyer-Lueckel and Paris, Yang et al. obtained artificial tooth losses on the surface of enamel of bovine teeth during their studies on infiltrants in dentistry $[24,25]$. Mueller et al. used similar research material [26]. According to Buzalaf et al., human teeth can be regarded as the most appropriate source from the perspective of clinical relevance. But due to age, genetic and environmental influences (as fluoride and diet exposure, previous caries challenge) their composition is changeable. These differences imply variations to their response under acidic challenges. Permanent premolars and molars are the most commonly used in experiments. Primary teeth are occasionally used; they have a small surface for experimental manipulation and the progression of subsurface lesion in vitro is faster than would appear for permanent teeth. Caries progression should be expected to appear in a faster rate in partially erupted teeth. It is connected with the more porous structure of their surface. We can obtain some differences in dentin sclerosis, which occurs with age. On the other hand, bovine teeth compared to human teeth are: bigger, more available, have a more uniform composition and present a high level of porosity. Thus, providing a less variable response to demineralization and remineralization facilitates experimental manipulation and allows a faster diffusion of ions to the demineralized area.

The chemical model is the most common use during studies in the field of minimally invasive dentistry, as reported by literature [22, 24-26].

The most important factor taken into consideration when designing a method of controlled demineralization is to make a model as closely similar to the natural environment of the human oral cavity as it is possible. In vitro models allow us to maintain the stability and control over the environment and guarantee repeatability of the results. Those systems allow us to test and measure parameters such as: development of caries, from its initial phase to deep lesion, depth of lesion in enamel, loss of mineral content, hardness, use of fluorine and its losses and distribution of enamel. It is also easier to study $\mathrm{pH}$ of the environment in which the test takes place and to maintain stable conditions.

\section{Conclusions}

Based on the available literature, it was found that bovine teeth and human teeth with demineralization diagnosed while still inside the oral cavity are the most frequently used kind of specimens in research conducted with use of the chemical model. Not a single case of use of the biological and $\mathrm{pH}$-cycling models were found in the available literature related to the research of infiltrants in minimally invasive dentistry.

\section{References}

[1] Gębska A: Uzyskiwanie wczesnych postaci próchnicy szkliwa zębów ludzkich metodami in vitro. Praca doktorska, Pomorska Biblioteka Cyfrowa, Gdańsk 2009.

[2] Wójtowicz A, Malm A: Mikrobiologiczne podłoże próchnicy w aspekcie jej profilaktyki. Farm Pol 2009, 65, 327-330.

[3] Fejerskov O, Kidd E: Próchnica zębów. Choroba próchnicowa i postępowanie kliniczne. Wydanie I polskie pod red. Kaczmarek U. Urban \& Partner, Wrocław 2006, 132-186.

[4] Krol DM: Dental caries, oral health, and pediatricians. Curr Probl Pediatr Adolesc Health Care 2003, 33, $253-270$.

[5] Jańczuk Z: Stomatologia zachowawcza. Wyd Lek PZWL, Warszawa 2008, 63-81.

[6] Cameron AC, Widmer RP: Stomatologia dziecięca. Wydanie II polskie pod red. Kaczmarek U. Urban \& Partner, Wrocław 2012, 188-237.

[7] He LH, Swain MV: Understanding the mechanical behaviour of human enamel from its structural and compositional characteristics. J Mech Behav Biomed Mater 2008, 1, 18-29.

[8] Sierpińska T, Stocka A, Gołębiewska M: Struktura szkliwa, właściwości śliny oraz bruksizm jako czynniki etiologiczne odpowiedzialne za starcie patologiczne. Przegląd piśmiennictwa. Protet Stomatol 2008, 58, 100-104.

[9] Kaczmarek U: Mechanizmy kariostatyczne fluoru. Czas Stom 2005, 58, 404-413. 
[10] Ilewicz L, Skucha-Nowak M, Renk S: Zastosowanie chemo-mechanicznego systemu „Carisolv” w usuwaniu próchnicowo zmienionej zębiny. Twój Mag Med - Stomatologia i Protetyka 2002, 7, 30-38.

[11] Lewandowska KD: Czy subdyfuzja warunkuje rozwój próchnicy szkliwa? Ann Acad Med Gedan 2005, 35, $133-138$.

[12] Piesiak-Pańczyszyn D, Czajczyńska-Waszkiewicz A, Kaczmarek U: Analiza porównawcza ultrastrukturalnego obrazu i składu chemicznego wczesnej zmiany próchnicowej i zdrowych tkanek twardych zębów. Dent Med Probl 2005, 42, 443-448.

[13] Torres CRG, Borges AB, Torres LMS, Gomes IS, Oliveira RS: Effect of caries infiltration technique and fluoride therapy on the colour masking of white spot lesions. J Dent 2011, 39, 202-207.

[14] Skucha-Nowak M, Tanasiewicz M, Gibas M, Twardawa H: Analysis of the composition of preparations used as a barrier to protect tissues of the patient against the influence of the environment in the oral cavity. Pol J Environ Stud 2013, 22, 53-57.

[15] Skucha-Nowak M, Tanasiewicz M, Gibas M, Twardawa H: Barriers securing the patient's own tissues against of the oral cavity environment than can be used in low invasive dentistry. Pol J Environ Stud 2012, 21, 25-29.

[16] Buskes JAKM, Christofferson J, Arends J: Lesion formation and lesion remineralization in enamel under constant composition conditions. A new technique with application. Caries Res 1985, 19, 490-496.

[17] Loba-Jakubowska E: Bisfosfoniany - nadzieja na skuteczne leczenie osteoporozy w wieku rozwojowym. Przegl Pediatr 2003, 33, 261-264.

[18] Chmielewska E: Nowe bisfosfoniany jako potencjalne leki przeciw osteoporozie. Praca doktorska. Politechnika Wrocławska 2010.

[19] Chu JS: The role of fluoride in mineral dissolution and remineralization of dental enamel. Praca doktorska. The University of Utah 1989.

[20] Fan Y: Effects of different finishing procedures and materials on surface roughness of infiltrated subsurface bovine enamel lesions. Praca doktorska, Universitätsmedizin, Berlin 2010.

[21] Buzalaf MA, Hannas AR, Magalhăes AC, Rios D, Honório HM, Delbem AC: pH-cycling models for in vitro evaluation of the efficacy of fluoridated dentifrices for caries control: strengths and limitations. J Appl Oral Sci 2010, 18, 316-334.

[22] Meyer-Lueckel H, Paris S: Improved Resin Infiltration of Natural Caries Lesions. J Dent Res 2008, 87, 1112-1116.

[23] Meyer-Lueckel H, Paris S, Kielbassa AM: Surface Layer Erosion of Natural Caries Lesions with Phosphoric and Hydrochloric Acid Gels in Preparation for Resin Infiltration. Caries Res 2007, 41, 223-230.

[24] Meyer-Lueckel H, Paris S: Progression of Artificial Enamel Caries Lesions after Infiltration with Experimental Light Curing Resins. Caries Res 2008, 42, 117-124.

[25] Yang F, Mueller J, Kielbassa A: Surface substance loss of subsurface bovine enemel lesions after different steps of the resinous infiltration technique: 3D topography analysis. Odontology 2012, 100, 172-180.

[26] Mueller J, Yang F, Neumann K, Kielbassa A: Surface tridimensional topography analysis of materials and finishing procedures after resinous infiltration of subsurface bovine enamel lesions. Quintessence Int 2011, 42, $135-147$.

\section{Address for correspondence:}

Małgorzata Skucha-Nowak

Department of Conservative Dentistry with Endodontics

Medical University of Silesia

Pl. Akademicki 17

41-902 Bytom

Poland

E-mail: mskucha-nowak@sum.edu.pl

Conflict of interest: None declared

Received: 21.02 .2014

Revised: 8.09.2014

Accepted: 23.09.2014 